\title{
Aktualność koncepcji „ekologii rodziny” zawartej w encyklice Centesimus annus
}

\section{Wstęp}

Zagadnienie ekologii jest dzisiaj w Kościele coraz bardziej popularne. W dużym stopniu przyczyniła się do tego encyklika papieża Franciszka Laudato si'. Emocje i komentarze, które wzbudziła, świadczą o żywym zainteresowaniu tą tematyką. Franciszkowa idea ekologii integralnej nawiązuje do dorobku poprzednich papieży i soborowego nauczania Kościoła, w którym podejmowane były istotne kwestie ekologiczne ${ }^{1}$. Warto w tym względzie zwrócić uwagę na nauczanie Jana Pawła II i jego encyklikę Centesimus annus.

Analiza treści encykliki pod kątem zaproponowanego tematu ogranicza poszukiwania do wątku ekologicznego. Jego przybliżenie jest konieczne, by dostrzec, jak wielką rolę w świecie odgrywają człowiek, rodzina i przyroda. Zostanie dokonana analiza pojęcia ekologii ludzkiej, ekologii rodziny, błędu antropologicznego oraz obszarów funkcjonowania rodziny dążącej do miana rodziny ekologicznej. Odniesienie wyników otrzymanych w trakcie analiz do polityki społecznej państwa oraz założeń pedagogiki społecznej pozwoli na wskazanie kierunków przemian dokonujących się w ekologii rodziny w ostatnim dwudziestopięcioleciu oraz zaproponowanie kierunków dalszych działań.

1 J. Brusiło, Teologia praktyczna i ekologia, Kraków 2015. 


\section{Ekologia rodziny w kontekście ekologii ludzkiej}

Nauczanie papieża dotyczące „kwestii ekologicznej” poszerza tradycyjne rozumienie ekologii. Jan Paweł II wynosi zakres jej rozumienia poza środowisko naturalne: „Oprócz irracjonalnego niszczenia środowiska naturalnego należy tu przypomnieć bardziej jeszcze niebezpieczne niszczenie środowiska ludzkiego, czemu zresztą bynajmniej nie poświęca się koniecznej uwagi. Podczas gdy słusznie, choć jeszcze nie w dostatecznej mierze, okazuje się troskę o zachowanie naturalnego «habitat» różnych gatunków zwierząt zagrożonych wymarciem, wiedząc, że każdy z nich wnosi swój wkład w ogólną równowagę ziemi, to zbyt mało wagi przywiązuje się do ochrony warunków moralnych prawdziwej «ekologii ludzkiej»"

Pojęcie „ekologia ludzka”, łączące w sobie klasyczne pojęcie ekologii i teologii, zwłaszcza moralnej ${ }^{3}$, nie jest związane wyłącznie $\mathrm{z}$ myślą papieską. Jan Paweł iI wykorzystał to pojęcie, by pokazać, jak ważnym zagadnieniem jest ekologiczna troska o człowieka w szerokim wymiarze jego egzystencji. Stanisław Zięba zauważa, że ekologia człowieka rozpoczęła się wraz z pojawieniem się człowieka w przyrodzie, zaś termin ten pojawił się w 1910 roku. W literaturze przedmiotu stosuje się różne określenia ekologii człowieka, np. ekologia humanistyczna, ekologia antropologiczna czy antropologia przyrodnicza ${ }^{4}$. Elementem łączącym te różne ujęcia jest przedmiot ich zainteresowania: „Przedmiotem ekologii stał się człowiek, a ściślej: jego usytuowanie wobec natury i społeczeństwa. Z jednej strony gatunek biologiczny, którego natura jest rezultatem biologizmu, $\mathrm{z}$ drugiej strony dzięki kulturze gatunek ten jest zdolny przekroczyć naturę"s.

Rozważając naturę ekologii ludzkiej, autor Centesimus annus zwraca uwagę na pojęcie nierozerwalnie z nią związane, czyli na ekologię rodziny. Autor jubileuszowej encykliki zauważa, że rodzina jest „pierwszą i podstawową komórką «ekologii ludzkiej»" "Życie rodzinne, skupiające

2 CA 38.

M. Wyrostkiewicz, Ekologia ludzka. Osoba i jej środowisko z perspektywy teologicznomoralnej, Lublin 2007, s. 53-57.

4 S. Zięba, Historia myśli ekologicznej, Lublin 2004, s. 316.

5 Tamże.

${ }^{6}$ CA 39. 
wiele interakcji społecznych, najpełniej rozwija się w klimacie pozbawionym toksyczności i destrukcyjnego wpływu czynników zewnętrznych. Ekologia rodziny zakłada określoną jakość ludzkiego życia, czyli taki poziom, na którym są realizowane określone wartości i zaspokajane potrzeby członków rodziny. $\mathrm{W}$ tym znaczeniu jest ona synonimem dobrostanu?.

Warto zauważyć, iż we współczesnej ekologii ludzkiej można dostrzec jeszcze jeden ważny rys. Wiąże się on z bezpośrednim oddziaływaniem zewnętrznych czynników na środowisko wewnętrzne organizmu ludzkiego. Zagadnienie to jest określane jako ekologia środowiska wewnętrznego organizmu człowieka ${ }^{8}$ i wpisuje się w kontekst rozważań dotyczących relacji człowiek-środowisko. Ścisły związek pomiędzy nimi powoduje, że przyczyny zagrożeń życia koncentrują się wokół tego samego czynnika.

\section{Błąd antropologiczny}

Stosunek człowieka do przyrody, pełen harmonii i ładu, został zakłócony przez człowieka, czego efektem jest zagrożenie dalszego funkcjonowania człowieka i świata. Według Jana Pawła II zasadniczym powodem tego zakłócenia jest pojawienie się „błędu antropologicznego”, który obok konsumizmu, hedonizmu i praktycznego materializmu wpływa na destrukcję współczesnego świata. Błąd antropologiczny polega na odrzuceniu nadprzyrodzonego charakteru relacji Bóg-człowiek-przyroda ${ }^{9}$. Jan Paweł II tak opisuje to zjawisko: „Człowiek, opanowany pragnieniem posiadania i używania, bardziej aniżeli bycia i wzrastania, zużywa w nadmiarze i w sposób nieuporządkowany zasoby ziemi, narażając przez to także własne życie. U korzeni bezmyślnego niszczenia środowiska naturalnego tkwi błąd antropologiczny, niestety rozpowszechniony w naszych czasach. Człowiek, który odkrywa swą zdolność przekształcania

7 W. Bołoz, Ekologia rodziny w kontekście wspótczesnego społeczeństwa, „Studia Ecologiae et Bioethicae" 5 (2007), s. 20.

8 S. Sobczuk, Kryzys ekologiczny ostrzeżeniem i przestroga dla wspótczesnego świata i człowieka, „Rozprawy Społeczne” 7 (2013), s. 30.

9 J. Brusiło, Założenia chrześcijańskiej ekologii - aspekt etyczny, w: Elementy chrześcijańskie w edukacji ekologicznej. XVI Seminarium „Sacrum i przyroda”, red. M. Ostrowski, J. Partyka, Ojców 2008, s. 42. 
i w pewnym sensie stwarzania świata własną pracą, zapomina, że zawsze dzieje się to w oparciu o pierwszy dar, otrzymany od Boga na początku w postaci rzeczy przezeń stworzonych [...]. Zamiast pełnić rolę współpracownika Boga $\mathrm{w}$ dziele stworzenia, człowiek zajmuje Jego miejsce i w końcu prowokuje bunt natury, raczej przez niego tyranizowanej, niż rządzonej” ${ }^{\prime 10}$.

Przeakcentowanie ludzkiej roli wobec stworzenia powoduje, że godność ludzka - nawet uznawana i proklamowana - traci swoją najistotniejszą gwarancję. Dzieje się tak, ponieważ „negacja Boga pozbawia osobę jej fundamentu, a w konsekwencji prowadzi do takiego ukształtowania porządku społecznego, w którym ignorowana jest godność i odpowiedzialność osoby" ${ }^{\prime 1}$. Czysto antropocentryczne ukierunkowanie myślenia i działania człowieka koncentruje jego aktywność na zapewnieniu dobra przede wszystkim samemu sobie. W konsekwencji prowadzi to do nadmiernej i nieprzemyślanej konsumpcji zasobów przyrody, co „prowokuje bunt natury". Jego przejawem jest kryzys ekologiczny, który niezwykle szybko narasta ${ }^{12}$.

\section{Nawrócenie ekologiczne}

Proponowaną przez papieża formą przeciwdziałania jest nawrócenie ekologiczne. Jest ono związane z odrzuceniem fałszywej koncepcji absolutnej autonomii człowieka. Zakłada się, że relacja człowieka do Boga jest pierwszorzędna, ale jej istotnym uzupełnianiem jest stosunek człowieka do drugiego człowieka i do kosmosu ${ }^{13}$.

W nauczaniu społecznym Jan Paweł II dużą wagę przywiązuje do właściwego ułożenia relacji człowieka wobec świata. Dostrzega w niej kontekst moralny, który jest związany z godnością osoby ludzkiej, będącej źródłem i uzasadnieniem poszanowania życia każdej istoty jako bytu stworzonego przez Boga. Dlatego konieczne jest przyjęcie zasady,

${ }^{10}$ CA 37.

${ }^{11}$ CA 13.

12 S. Sobczuk, Kryzys ekologiczny ostrzeżeniem i przestroga dla współczesnego świata i człowieka, s. 25.

${ }^{13}$ J. Mariański, Problem ochrony środowiska i „ekologii ludzkiej”, w: Jan Paweł II, „Centesimus annus”. Tekst i komentarze, red. F. Kampka, C. Ritter, Lublin 1998, s. 326. 
że „najważniejszym motywem troski o środowisko jest dobro człowieka” ${ }^{14}$. Przyjęcie tego założenia sytuuje wartość środowiska pomiędzy skrajnymi ujęciami: absolutyzowaniem i marginalizowaniem ${ }^{15}$. Ta równowaga daje podstawy do podejmowania działań na rzecz przywrócenia integracji człowieka i świata, która konstytuuje ecologiae humanae. Stanisław Jaromi zauważa: „Główną osią integracji jest właściwa wizja życia, które manifestuje się zarówno w wymiarze biologicznym, jak i kulturowym, etycznym i religijnym. W ecologia humana życie w ogóle oraz życie i zdrowie człowieka ujmowane są jako wartości najwyższe, ale nie absolutne. Naczelną normą jest godność osoby ludzkiej [...]. Istotnym celem w działaniach prośrodowiskowych jest podnoszenie jakości ludzkiego życia i to zarówno w wymiarze materialnym, jak i duchowym i intelektualnym. Dążeniom tym powinny towarzyszyć takie wartości, jak odpowiedzialność, solidarność, sprawiedliwość, umiarkowanie i powściągliwość, pokój, wolność, prawda, miłość”16.

Odwołanie się do wartości jako fundamentu wzmocnienia bądź rekonstrukcji wizerunku ekologii ludzkiej określa kierunki działań. Oczekiwana zmiana opiera się na zaufaniu, że człowiek dysponuje zdolnościami do przewartościowania swoich dotychczasowych poczynań wobec środowiska naturalnego. Nadzieja na przejęcie odpowiedzialności za nie wiąże się z dowartościowaniem racjonalnych i moralnych uzdolnień

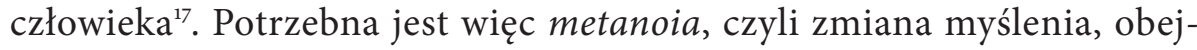
mująca wszystkie aspekty życia człowieka $\mathrm{w}$ relacji z Bogiem, drugim człowiekiem i przyrodą. Ta zmiana ma wpływ na głębokie pokłady ludzkiej aktywności i przynosi konkretne owoce. Dlatego Jan Paweł II zachęca, by „pobudzać i popierać «nawrócenie ekologiczne», które w ostatnich dziesięcioleciach sprawiło, że ludzkość stała się bardziej wrażliwa na niebezpieczeństwo katastrofy, do jakiej zmierzaliśmy [...]. Ma być to więc nie tylko «fizyczna» ekologia, starająca się o ochronę

${ }^{14}$ P. Kędzierski, Motywacja troski o zachowanie naturalnego środowiska w nauczaniu Jana Pawła II, w: Edukacja ekologiczna na progu XXI wieku. Stan - możliwości - programy, red. J. W. Czartoszewski, Warszawa 2001, s. 136.

${ }^{15}$ J. Dębowski, Ekologia osoby ludzkiej w chrześcijańskim nauczaniu społecznym, Olsztyn 2001, s. 135 .

${ }^{16}$ S. Jaromi, Koncepcja ekologii ludzkiej według Jana Pawła II, „Kwartalnik Naukowy Fides et Ratio" 2 (2012), s. 10-11.

${ }^{17}$ Z. Łepko, Antropologia kryzysu ekologicznego, Warszawa 2003, s. 141. 
środowiska rozlicznych istot żywych, lecz również ekologia «ludzka», która będzie czynić ich życie bardziej godnym, chroniąc istotne dobro życia we wszystkich jego formach i przygotowując przyszłym pokoleniom środowisko bliższe zamysłowi Stwórcy"18.

Nawrócenie ekologiczne jest kontynuacją tezy głoszonej przez papieża, że świat potrzebuje zauważenia i dowartościowania ekologii ludzkiej. Jest ona niezbędnym uzupełnieniem ekologii „fizycznej”. Bez tego humanistycznego odniesienia ekologia zajmująca się środowiskiem naturalnym mogłaby zagubić swe fundamentalne ukierunkowanie na dobro człowieka. Nawrócenie ekologiczne ma uczynić życie człowieka bardziej godnym i zapewnić życie kolejnym pokoleniom.

Założenia dotyczące poprawy sytuacji ekologii ludzkiej koncentrują się więc wokół zagadnienia funkcjonowania i przyszłości rodziny. Można przyjąć, że celem podejmowanych działań na rzecz ekologii rodziny jest stworzenie „rodziny ekologicznej”. Anna Latawiec definiuje ją jako strukturę, w której panuje pełna harmonia między „wewnętrznym” i „zewnętrznym” środowiskiem życia każdego jej członka. W rodzinie ekologicznej jest realizowany program nauczania naturalnego przebiegu rozwoju życia biologicznego. Są w niej kształtowane postawy oparte na odpowiedzialności, szacunku do życia i respektowaniu praw każdego człowieka. Jest to rodzina zdrowa moralnie i społecznie ${ }^{19}$.

Do realizacji wyznaczonych zadań konieczna jest odpowiednia polityka społeczna oraz wychowanie ekologiczne, pobudzające aktywność człowieka. Jego aktywność „W procesie przekształcania środowiska prowadzi do zmiany warunków życia, co wtórnie oddziałuje na niego samego, decyduje o jego zdrowiu" ${ }^{20}$. Dzięki temu szanse na zwiększenie świadomości i zachowań ekologicznych wzrastają. By móc podejmować skuteczne działania, należy określić ich zakres.

\footnotetext{
${ }^{18}$ Jan Paweł II, Katecheza (17 I 2001), „L'Osservatore Romano”, wyd. polskie, 4 (2001), s. 44 .

${ }_{19}$ A. Latawiec, Rodzina ekologiczna - co to jest?, w: Ekologia rodziny ludzkiej, red. J. M. Dołęga, J. W. Czartoszewski, Olecko 2000, s. 56-57.

${ }^{20}$ N. Wolański, A. Siniarska, Wychowanie do środowiska $w$ świetle ekologii człowieka, w: Edukacja ekologiczna na progu XxI wieku..., s. 67.
} 


\section{Obszary rozwoju ekologii rodziny}

Troska o ekologiczny wymiar życia rodzinnego inspiruje do refleksji dotyczącej wpływu czynników zewnętrznych na przemiany ekosystemu rodzinnego. Oddziałują one na istotne pola aktywności ludzkiej i prowadzą do rozwoju bądź dekonstrukcji rodziny. Ważne są także czynniki wewnątrzrodzinne, które wpływają na poziom ekologicznego funkcjonowania rodziny. Ich wzmocnienie dokonuje się między innymi poprzez odpowiednią politykę społeczną i działania wychowawcze. Obecnie szczególnie wymagana jest „ «elastyczna» kultura polityczna, sprzyjająca potrzebom i możliwościom wykorzystania dynamiki nowoczesnej gospodarki i w ogóle dynamiki postępu cywilizacyjnego do przekształcenia dominującego dzisiaj w świecie jednowymiarowego paradygmatu ekonomicznego w wielowymiarowy paradygmat ekologiczny" ${ }^{21}$.

Budowanie wielowymiarowego paradygmatu ekologicznego nie powinno pomijać obszarów związanych z codziennym życiem rodziny, a te dotyczą realizacji procesu wychowania. Pedagogiczne założenia działań proekologicznych znalazły odniesienia np. w pedagogice ekologicznej, kształtującej w człowieku pozytywne nastawienie do środowiska i związanych z nim wartości ${ }^{22}$. Na podstawie lektury Centesimus annus można przyjąć, że budowanie ekologii rodziny dokonuje się na kilku płaszczyznach, spośród których warto wyodrębnić następujące.

\section{I. Pogłębienie tożsamości rodziny}

Nie sposób przecenić roli rodziny w nauczaniu Jana Pawła II. W encyklice Centesimus annus papież zwraca uwagę na jej funkcje. Ich realizacja zapewnia rozwój człowieka w klimacie miłości. To w rodzinie „człowiek otrzymuje pierwsze i decydujące wyobrażenia związane z prawdą i dobrem, uczy się, co znaczy kochać i być kochanym, a więc co konkretnie znaczy być osobą"²3. Jak zauważa Jan Mazur, „świadomość bezinteresownego daru z siebie, przez który człowiek «urzeczywistnia siebie samego»,

\footnotetext{
${ }^{21}$ Z. Łepko, Antropologia kryzysu ekologicznego, s. 185.

${ }^{22}$ E. Albińska, Pedagogika ekologiczna, w: Encyklopedia pedagogiczna xxI wieku, t. 4, red. T. Pilch, Warszawa 2005, s. 129-134.

${ }^{23}$ CA 39.
} 
musi być stale odnawiana i stale zabezpieczana" ${ }^{24}$. Jednym ze sposobów odnawiania tej świadomości jest nieustanne pogłębianie tożsamości człowieka. Odkrywanie to nierozerwalnie łączy się z odniesieniem do tożsamości rodziny, której jest on członkiem. Papież zwraca uwagę na ważną kwestię, która również dzisiaj przyczynia się do destrukcji rodziny. Jest nią odejście od definicji rodziny opartej „na małżeństwie, gdzie wzajemny dar z samego siebie, mężczyzny i kobiety, stwarza takie środowisko życia, w którym dziecko może się urodzić i rozwijać swe możliwości”25.

Redefinicja rodziny i małżeństwa wprowadza bezład w miejsce harmonii stworzenia. Przyjęcie założenia, że „tradycyjne” rozumienie rodziny to wynik implikacji związanej z określoną religią ${ }^{26}$ jest formą niedopuszczalnego redukcjonizmu. Jego ekspansja, zasygnalizowana przez papieża, jest widoczna w wielu krajach świata. O ile w czasach powstania Centesimus annus zakres omawianego zjawiska był stosunkowo ograniczony, obecnie heterogeniczność rodziny jest zjawiskiem powszechnym i wiąże się z wpływem tzw. westernizacji. Przenoszenie wzorów życia rodzinnego z krajów zachodnich jest związane z promowaniem wartości o charakterze indywidualistycznym, takich jak niezależność czy autonomia ${ }^{27}$.

Przeciwdziałanie tym zjawiskom wymaga wspomnianego już nawrócenia ekologicznego, które w tym przypadku można określić jako formę przeciwstawienia się toksycznym relacjom i poglądom, usiłującym zminimalizować potencjał miłości rodzinnej. Pogłębienie tożsamości rodziny jest zadaniem każdej rodziny, ale potrzebuje także wsparcia odpowiednio prowadzonej społecznej polityki państwa. Niestety nie zawsze jest ona wydolna. Dlatego warto dostrzegać i wzmacniać wszystkie inicjatywy służące ekologii rodziny ${ }^{28}$. Ważne jest także wsparcie o charakterze

${ }^{24}$ J. Mazur, Jana Pawła II nauczanie o rodzicielstwie, „Roczniki Nauk Społecznych” 3 (2011), s. 127.

${ }^{25}$ CA 39.

${ }^{26}$ A. Breczko, O potrzebie redefinicji pojęć „małżeństwo” $i$ „rodzina” we współczesnym pluralistycznym świecie. Rozważania w kontekście związków partnerskich, „Miscellanea Historico-Iuridica" 13 (2014), s. 339.

${ }^{27}$ L. Bakiera, Rodzina z perspektywy socjologicznej i psychologicznej: ciagłość i zmiana, „Roczniki Socjologii Rodziny” 17 (2006), s. 102.

${ }^{28}$ Warto zauważyć dobre tendencje społeczne, które niekiedy sprzeciwiają się polityce państwa, czego przykładem może być odrzucenie przez Słoweńców prawa osób homoseksualnych do zawierania małżeństwa. Warto podkreślić, że wynik referendum ogranicza dotychczasowe prawo, które było w tym względzie liberalne. Zob. Słoweńcy odrzucili w re- 
edukacyjnym, ukazujące piękno rodziny. Poszerzanie świadomości i uwrażliwianie na kwestie ekologiczne wpływa na kształtowanie postaw, wartości i umiejętności koniecznych do wprowadzenia w codzienne życie zasad rozwoju zgodnego z naturą człowieka.

\subsection{Dobre wykorzystanie wolności}

Spośród wielu znaczeń wolności na szczególną uwagę zasługuje wolność rozumiana jako możliwość podejmowania decyzji i stanowienia o sobie. Zakłada ona istnienie dychotomii pomiędzy podjęciem jakiegoś zadania a powstrzymaniem się od niego. W tym kontekście wolność wyboru może być rozumiana jako możliwość wyboru spośród wielu przedmiotów działania. Przyjmuje się, że bardziej wolny jest ktoś, kto nie dokonał wyboru, bo wybór jednej z możliwych dróg powoduje utratę wolności ${ }^{29}$. Takie rozumienie wolności krytykuje Jan Paweł II, gdyż generuje ono postawę obojętności, konformizmu i zniechęcenia wobec miłości i życia: „Często się jednak zdarza, że zniechęcony do tworzenia autentycznych warunków ludzkiej prokreacji człowiek skłania się do traktowania siebie samego i własnego życia raczej jako zespołu doznań, których należy doświadczyć, aniżeli dzieła, które ma wypełnić. Stąd się wywodzi brak wolności, $\mathrm{a} \mathrm{w}$ konsekwencji rezygnacja $\mathrm{z}$ angażowania się $\mathrm{w}$ stały związek $\mathrm{z}$ inną osobą i rodzenie dzieci, lub skłonność do uważania ich za jedną z wielu «rzeczy», które można mieć lub nie mieć, według własnych upodobań, i które współzawodniczą z innymi możliwościami”"

Złe wykorzystanie wolności przejawia się między innymi poprzez inercję woli, kształtującą się w kulturze tymczasowości. Komentując to zjawisko, Carlos G. Vallés pisze: „Większość decyzji podejmuje się na tym świecie przez niepodejmowanie ich (jest to już jakaś decyzja), raczej przez unikanie działania niż działanie, przez pozostawienie rzeczy ich dotychczasowemu biegowi [...]. Brak decyzji jest najgorszą z decyzji. Inercja wolitywna jest chorobą śmiertelną"31.

ferendum małżeństwa osób homoseksualnych, http://wiadomosci.onet.pl/swiat/slowency-odrzucili-w-referendum-malzenstwa-osob-homoseksualnych/gvhzbn (28.01.2016).

${ }^{29}$ W. Starnawski, Bycie osobą. Podstawy moralności i wychowania, Warszawa 2011, s. 34.

${ }^{30}$ CA 39.

${ }^{31}$ C. G. Vallés, Sztuka wyboru, tłum. K. Homa, Kraków 2004, s. 30. 
Przeciwdziałanie złemu wykorzystaniu wolności polega między innymi na dowartościowaniu znaczenia własnego sprawstwa podmiotu ludzkiego. Samostanowienie pozwala uniknąć paradoksu ograniczenia wolności z powodu dokonania wyboru dobra, a co za tym idzie, wzmacnia zakres wolności człowieka. Jest szczególnie ważne w budowaniu ekologicznego wymiaru życia rodziny. Domaga się ona wykorzystania jednego z wymiarów ekologicznej polityki prewencyjnej ${ }^{32}$, zapobiegającej kreowaniu niewłaściwych modeli życia społecznego. Istotne jest przeciwdziałanie konsumizmowi, co według papieża dokonuje się poprzez pracę na płaszczyźnie wychowania i kultury, obejmującą przygotowanie do odpowiedzialnego korzystania z prawa wyboru ${ }^{33}$. Te działania mogą się przyczynić do wzmocnienia postaw jednostek, które nie poddają się inercji, bezwładowi popkultury i konsumizmowi. Mogą także stać się bodźcem dla osób, dla których sytuacje decyzyjne są szczególnie trudnym wyzwaniem.

\subsection{Ochrona życia}

Ekologia rodziny zakłada uwzględnienie jej sakralnego charakteru. Jan Paweł II nazywa rodzinę „sanktuarium życia”, przez co wskazuje, że jest ona „miejscem, w którym życie, dar Boga, może w sposób właściwy być przyjęte i chronione przed licznymi atakami, na które jest ono wystawione, może też rozwijać się zgodnie z wymogami prawdziwego ludzkiego wzrostu. Wbrew tak zwanej kulturze śmierci, rodzina stanowi ośrodek kultury życia" ${ }^{34}$.

Ludzki wzrost, dokonujący się w atmosferze rodzinnej, sprzyjającej życiu, jest odpowiedzią na zaproszenie człowieka do współpracy z Bogiem w akcie stwórczym. Przekazanie życia, jego ochrona oraz troska o prawidłowy rozwój stanowią formę dialogu z Bogiem. Związek płci z ekologią nabiera znaczenia w perspektywie poczętego życia i jest świadectwem „świadomości ekologicznej” ${ }^{35}$, niezmiernie istotnej dla dalszych losów ludzkości. W tym kontekście Włodzimierz Fijałkowski stawia pytanie:

\footnotetext{
32 Z. Łepko, Antropologia kryzysu ekologicznego, s. 185-186.

33 Por. CA 36.

34 CA 39.

35 W. Fijałkowski, Ekologia rodziny. Ekologiczna Odnowa Prokreacji, Kraków 2001, s. 9.
} 
„Czy można przejść do porządku dziennego nad tym, że człowiek niszczy samego siebie w sferze istotnej dla «być albo nie być» gatunku - w dziedzinie prokreacji?”" Szukając odpowiedzi, autor stwierdza: „Ekologia ma wyraźne odniesienie do aksjologii: życie traktuje jako podstawową wartość, a środowisko społeczno-przyrodnicze jako dobro wspólne" ${ }^{\prime 37}$.

Troska o ochronę sanktuarium życia, niezwykle bliska Janowi Pawłowi II, powinna się wyrażać w ochronie życia od poczęcia aż do naturalnej śmierci. W ten sposób zostaje zabezpieczone życie - najważniejsza wartość ekologiczna na ziemi. Problematyka świętości życia rozważana w świetle polityki społecznej państw napotyka na utrudnienia związane z wadliwym ustawodawstwem, które nie zawsze w pełni troszczy się o ludzkie życie ${ }^{38}$. Społeczna dyskusja nad prawdziwie ekologicznymi regulacjami dotyczącymi ochrony życia człowieka często pozostaje na poziomie postulatów. W tym kontekście coraz większego znaczenia nabiera wymiar wychowawczy troski o „sanktuarium życia”.

Rozwój pedagogiki prenatalnej spowodował, że poczęte życie stało się obszarem badań pedagogicznych. Dorota Kornas-Biela stawia w tym kontekście śmiały postulat: „Słowo ekologia pochodzi od greckiego słowa oikos, co znaczy dom. Tym pierwszym «domem» zamieszkania człowieka jest łono matki. Trzeba więc udomowić łono matki i rozpoznać tego, kto ten dom zamieszkuje" ${ }^{39}$. Spojrzenie na łono matki, rozumiane jako pierwsze uczuciowe środowisko życia dziecka i podstawowy ekosystem, którego dziecko jest ważnym elementem, pozwala na dowartościowanie życia. Dostrzeżenie świętości sanktuarium życia ludzkiego jest więc niezbędnym warunkiem odkrywania pełnego znaczenia ekologii rodziny.

\section{Zakończenie}

Poruszona przez Jana Pawła II kwestia ekologiczna ma istotne znaczenie dla losów świata i człowieka. Ekologia rodziny, stanowiąca jądro ekologicznej troski o dobro człowieka i świata, jest papierkiem lakmusowym

\footnotetext{
${ }^{36}$ Tamże, s. 92.

${ }^{37}$ Tamże.

${ }^{38}$ D. Kornas-Biela, Ekologia łona ekologia świata. O nowy paradygmat w ekologii, w: Ekologia rodziny ludzkiej, s. 103-105.

${ }_{39}$ Tamże, s. 103-108.
} 
współczesnej polityki społecznej i działań zmierzających do poprawy jakości życia w rodzinie. Zaprezentowanie zakresu obejmującego ekologię rodziny pozwoliło na przybliżenie zagadnienia, które w kontekście kampanii ekologicznych jest często pomijane. Tymczasem troska o właściwy rozwój rodziny jest jednym $\mathrm{z}$ najistotniejszych zadań stojących przed współczesnym człowiekiem.

Autor Centesimus annus dokonał rzeczy znamienitej. W prosty sposób wyraził postulat troski o zachowanie i rozwijanie ekologicznego wymiaru życia rodziny. Rozszerzenie rozumienia ekologii na obszary związane z życiem człowieka w rodzinie pokazało nowe aspekty troski o jej rozwój. Wejrzenie w „rzeczy nowe” końca xx wieku pozwoliło na pokonanie dysonansu zawartego w powiedzeniu: „Chrześcijanie albo ekolodzy”. Zostało ono złagodzone do stwierdzenia: „Chrześcijanie i ekolodzy”, a w konsekwencji: „Chrześcijanie jako ekolodzy”.

Zagadnienie ekologii ludzkiej i ekologii rodziny stanowi na pozór epizodyczny wątek poruszony w papieskiej encyklice. Jednak dokładniejsza analiza jej treści pokazała, że chociaż papież poświęcił tej tematyce niewielką część swojej wypowiedzi, to jest ona dobrze wkomponowana w całość rozważań na temat społecznych aspektów życia człowieka. Ekologia rodziny jest osadzona na fundamentach niezmiennych wartości, dzięki czemu można określić obszary jej rozwoju. Idąc za myślą papieską, przyjęto, że szczególnie aktualnymi aspektami tworzenia się rodziny ekologicznej są: pogłębienie jej tożsamości, dobre wykorzystanie wolności i dostrzeżenie konieczności zadbania o ochronę życia ludzkiego.

Wszystkie postulaty dotyczące realizacji założeń budowania ekologicznej rodziny są związane z polityką społeczną państwa i pedagogiką społeczną. W przeprowadzonych analizach zwrócono uwagę na te dwie płaszczyzny działań społecznych, gdyż jak się wydaje, są one ze sobą ściśle związane i w dużym stopniu od siebie zależne. Współdziałanie polityki i pedagogiki społecznej otwiera perspektywy podejmowania działań, przeciwstawiających się skutkom błędu antropologicznego i szanujących wolność człowieka. Trzeba mieć nadzieję, że postawione postulaty będą realizowane w działalności społecznej w naszym kraju i na całym świecie.

${ }^{40}$ P. de Plunkett, Ekologia - stereotypy i rzeczywistość. Od Biblii do naszych czasów, tłum. S. Filipowicz, Poznań 2008, s. 294-307. 


\section{Bibliografia}

Albińska E., Pedagogika ekologiczna, w: Encyklopedia pedagogiczna xxI wieku, t. 4, red. T. Pilch, Warszawa 2005, s. 129-134.

Bakiera L., Rodzina zperspektywy socjologicznej i psychologicznej: ciagłość i zmiana, „Roczniki Socjologii Rodziny” 17 (2006), s. 101-115.

Bołoz W., Ekologia rodziny w kontekście współczesnego społeczeństwa, „Studia Ecologiae et Bioethicae" 5 (2007), s. 9-22.

Breczko A., O potrzebie redefinicji pojęć „małżeństwo” $i$ „rodzina” we współczesnym pluralistycznym świecie. Rozważania w kontekście związków partnerskich, „Miscellanea Historico-Iuridica” 12 (2014), s. 335-352.

Brusiło J., Teologia praktyczna i ekologia, Kraków 2015.

Brusiło J., Założenia chrześcijańskiej ekologii - aspekt etyczny, w: Elementy chrześcijańskie w edukacji ekologicznej. Xvi Seminarium „Sacrum i przyroda”, red. M. Ostrowski, J. Partyka, Ojców 2008.

Dębowski J., Ekologia osoby ludzkiej w chrześcijańskim nauczaniu społecznym, Olsztyn 2001.

Fijałkowski W., Ekologia rodziny. Ekologiczna odnowa prokreacji, Kraków 2001.

Jan Paweł II, „Centesimus annus”. Tekst i komentarze, red. F. Kampka, C. Ritter, Lublin 1998.

Jan Paweł II, Encyklika Centesimus annus, przedruk: Libreria Editrice Vaticana, Włocławek 1991.

Jan Paweł II, Trzeba zapobiec katastrofie ekologicznej (17 I 2001), „L'Osservatore Romano", wyd. polskie, 4 (2001), s. 43-44.

Jaromi S., Koncepcja ekologii ludzkiej według Jana Pawła II, „Kwartalnik Naukowy Fides et Ratio" 2 (2012), s. 5-12.

Kędzierski P., Motywacja troski o zachowanie naturalnego środowiska w nauczaniu Jana Pawła II, w: Edukacja ekologiczna na progu XXI wieku. Stan - możliwości - programy, red. J. W. Czartoszewski, Warszawa 2001.

Kornas-Biela D., Ekologia łona ekologia świata. O nowy paradygmat w ekologii, w: Ekologia rodziny ludzkiej, red. J. M. Dołęga, J. W. Czartoszewski, Olecko 2000, s. 103-105.

Latawiec A., Rodzina ekologiczna - co to jest?, w: Ekologia rodziny ludzkiej, red.

J. M. Dołęga, J. W. Czartoszewski, Olecko 2000, s. 43-57.

Łepko Z., Antropologia kryzysu ekologicznego, Warszawa 2003. 
Mariański J., Problem ochrony środowiska i „ekologii ludzkiej”, w: Jan Paweł II, „Centesimus annus”. Tekst i komentarze, red. F. Kampka, C. Ritter, Lublin 1998, S. 325-339.

Mazur J., Jana Pawła II nauczanie o rodzicielstwie, „Roczniki Nauk Społecznych” 3 (2011), s. 119-138.

Plunkett P. de, Ekologia - stereotypy i rzeczywistość. Od Biblii do naszych czasów, tłum. S. Filipowicz, Poznań 2008.

Słoweńcy odrzucili $w$ referendum małżństwa osób homoseksualnych, http:// wiadomosci.onet.pl/swiat/slowency-odrzucili-w-referendum-malzenstwa-osob-homoseksualnych/gvhzbn (28.01.2016).

Sobczuk S., Kryzys ekologiczny ostrzeżeniem i przestroga dla współczesnego świata i człowieka, „Rozprawy Społeczne” 2 (2013), s. 25-33.

Starnawski W., Bycie osobą. Podstawy moralności i wychowania, Warszawa 2011. Vallés C. G., Sztuka wyboru, tłum. K. Homa, Kraków 2004.

Wolański N., Siniarska A., Wychowanie do środowiska wświetle ekologii człowieka, w: Edukacja ekologiczna na progu XXI wieku. Stan - możliwości - programy, red. J. W. Czartoszewski, Warszawa 2001.

Wyrostkiewicz M., Ekologia ludzka. Osoba i jej środowisko z perspektywy teologicznomoralnej, Lublin 2007.

Zięba S., Historia myśli ekologicznej, Lublin 2004.

\section{Abstrakt}

Wątek ekologiczny zawarty w encyklice Centesimus annus ukierunkowuje myślenie ekologiczne na rodzinę. Ona jest jądrem ekologii ludzkiej i ku jej rozwojowi winny zmierzać działania społeczne. Papieskie nauczanie dotyczące ekologicznego wymiaru życia rodziny wskazuje na wartości, które stanowią fundament troski o przyszłość człowieka i świata. Rozszerzenie zakresu ekologii na płaszczyznę życia rodzinnego przyczynia się do rozwoju tożsamości w rodzinie, kształtowania postaw prawidłowego wykorzystania wolności oraz troski o życie człowieka. Obszary te wchodzą w zakres polityki społecznej państwa i działalności pedagogicznej. 
Topicality of the concept of „ecology of the family” in the encyclical Centesimus annus

\begin{abstract}
The issue of ecology, included in the encyclical Centesimus annus, focuses on the family. The family is in the centre of human ecology and its development should be boosted by social action. The Pope's teaching on the ecological dimension of the family life highlights values which form the basis of care about the future of humanity and the world. Extending the scope of ecology to the family life helps to develop the identity in the family, to use freedom properly and to care about life. These areas are part of educational action and social policy of the country.
\end{abstract}

